\title{
PENERAPAN PENDEKATAN OPEN-ENDED \\ DALAM MENINGKATKAN HASIL BELAJAR KETERAMPILAN BERBICARA
}

\author{
M. Zulham \\ Program Studi Pendidikan Bahasa dan Sastra Indonesia, FKIP, Universitas Cokroaminoto Palopo \\ Jalan Anggrek, Tompotika, Kota Palopo \\ email: m.zulham92@yahoo.co.id
}

DOI: $10.26858 /$ retorika.v 10i2.4852

\begin{abstract}
Applying Open-Ended Approach in Improving Students' Speaking Learning Outcomes. The objectives of this research are to find out the speaking learning outcomes. This study is an experimental research. The experimental unit in this research is the eighth grade students of SMP Negeri 1 Ponrang Selatan in academic year 2015/2016. In Selecting of experimental class, the researcher applies random sampling technique. The instrument of this study is a test of learning outcomes of pretest and posttest. The result of this research are: (1) speaking learning outcomes before applying open-ended approach is medium category; otherwise, speaking learning outcomes after applying open-ended approach is high category, (2) there is an improvement of students' speaking learning outcomes after applying open-ended approach.
\end{abstract}

\begin{abstract}
Abstrak: Penerapan Pendekatan Open-Ended dalam Meningkatkan Hasil Belajar Keterampilan Berbicara. Penelitian ini bertujuan untuk mengetahui hasil belajar berbicara siswa. Penelitian ini termasuk penelitian eksperimen. Satuan eksperimen dalam penelitian ini adalah siswa kelas VIII SMP Negeri 1 Ponrang Selatan tahun pelajaran 2015/2016. Pemilihan kelas eksperimen dalam penelitian ini dilakukan dengan menggunakan teknik random sampling. Instrumen yang digunakan dalam penelitian ini adalah tes hasil belajar yang terdiri dari pretest dan posttest. Hasil dari penelitian ini adalah (1) hasil belajar berbicara siswa sebelum diterapkan pendekatan open-ended berada pada kategori sedang dan setelah diterapkan pendekatan openended berkategori tinggi, (2) terjadi peningkatan hasil belajar berbicara sis wa secara signifikan.
\end{abstract}

Kata kunci: pendekatan open-ended, keterampilan berbicara

Bahasa Indonesia adalah salah satu kajian linguistik yang membekali siswa dengan kemampuan berbahasa (berbicara, menyimak, menulis, dan membaca), baik kemampuan itu diaplikasikan dalam bentuk lisan maupun tulisan dalam kehidupan sehari-hari. Permendiknas Nomor 22 Tahun 2006 tentang Standar Isi dan Standar Kompetensi Kurikulum 2006 mengamanatkan agar pembelajaran di sekolah berlangsung secara alamiah. Pendekatan pengajaran yang menempatkan guru sebagai sentral kegiatan belajar-mengajar sedikit demi sedikit mulai ditinggalkan.

Dalam konteks pembelajaran bahasa Indonesia, pengajaran bahasa Indonesia dikemba- likan pada kedudukan yang sebenarnya, yaitu melatih siswa membaca, menulis, berbicara, mendengarkan, dan mengapresiasi karya sastra. Tujuan pengajaran pengajaran bahasa dan sastra Indonesia adalah melatih siswa meningkatkan kemampuan berbahasa Indonesia, baik lisan maupun tulisan secara nyata. Atas dasar itu, pengajaran bahasa Indonesia sebaiknya diisi oleh kegiatan-kegiatan yang melatih siswa membaca sebanyak-banyaknya, menulis sebanyakbanyaknya, berdiskusi sebanyak-banyaknya, dan mendengarkan sebanyak-banyaknya.

Menurut Nisbet (dalam Suherman, 2001), tidak ada cara belajar tunggal yang paling benar dan cara mengajar yang paling baik. Orang- 
orang berbeda dalam kemampuan intelektual, sikap, dan kepribadian sehingga mereka mengadopsi pendekatan-pendekatan yang karakteristiknya berbeda untuk belajar. Dari sini dapat dikatakan bahwa masing-masing individu akan memilih cara dan gayanya sendiri untuk belajar dan guru juga akan memilih cara dan gayanya sendiri untuk mengajar. Namun demikian, setidak-tidaknya ada karakteristik tertentu dalam pendekatan pembelajaran tertentu yang khas dibandingkan dengan pendekatan lain.

Pendekatan open-ended sebagai salah satu pendekatan dalam pembelajaran merupakan suatu pendekatan yang memungkinkan siswa untuk mengembangkan pola pikirnya sesuai dengan minat dan kemampuan masing-masing. Hal ini disebabkan karena pada pendekatan open-ended, formulasi masalah yang digunakan adalah masalah terbuka. Masalah terbuka adalah masalah yang diformulasikan memiliki multijawaban (banyak penyelesaian) yang benar. Di samping itu, melalui pendekatan open-ended, siswa dapat menemukan sesuatu yang baru dalam penyelesaian suatu masalah, khususnya masalah yang berkaitan dengan bahasa Indonesia. Dengan dasar itu, maka pendekatan open-ended dapat diterapkan dalam proses pembelajaran dalam kelas di sekolah.

Selain masalah metode, strategi, dan pendekatan, masalah lain yang menjadi penyebab rendahnya hasil belajar siswa adalah formulasi masalah yang digunakan dalam pembelajaran bahasa Indonesia. Selama ini formulasi masalah yang sering digunakan, baik pada tingkat dasar maupun lanjutan adalah masalah tradisional. Dikatakan tradisional karena masalah yang diajukan oleh guru sudah diformulasikan dengan baik dengan jawaban yang benar adalah tunggal (hanya ada satu penyelesaian). Akibatnya, kreativitas dan kemampuan berpikir siswa tidak dapat berkembang secara maksimal dan pada saat yang sama kegiatan-kegiatan kreatif dari setiap siswa dapat terkomunikasikan selama proses pembelajaran.

Masalah yang diformulasikan memiliki multijawaban yang benar disebut problem tak lengkap atau disebut juga opend-ended problem atau masalah terbuka (Suherman, dkk. 2001). Pendapat yang sama juga dikemukakan oleh Shimada \& Becker (1997), yaitu bahwa ketika menyusun masalah yang diformulasikan memiliki multi-jawaban yang benar maka masalah itu disebut "masalah tak lengkap" atau open-ended sehingga dapat disimpulkan bahwa masalah open-ended adalah masalah yang memiliki multijawaban yang benar (banyak penyelesaian).

Sifat keterbukaan dari suatu masalah dikatakan hilang apabila hanya ada satu cara dalam menjawab permasalahan yang diberikan atau hanya ada satu jawaban yang mungkin untuk masalah tersebut. Contoh penerapan masalah open-ended dalam kegiatan pembelajaran adalah ketika siswa diminta mengembangkan metode, cara, atau pendekatan yang berbeda dalam menjawab permasalahan yang diberikan oleh guru.

Pembelajaran dengan pendekatan openended diawali dengan memberikan masalah terbuka kepada siswa. Kegiatan pembelajaran harus mengarahkan dan membawa siswa dalam menjawab masalah dengan banyak cara atau banyak jawaban yang benar. Hal ini dimaksudkan untuk merangsang kemampuan intelektual dan pengalaman siswa dalam proses menemukan sesuatu yang baru serta bertujuan agar kegiatan-kegiatan kreatif siswa dapat terkomunikasikan melalui proses pembelajaran.

Dalam pembelajaran bahasa Indonesia, rangkaian pengetahuan, keterampilan, konsep dan prinsip yang diberikan kepada siswa biasanya melalui langkah demi langkah atau bertahap agar kemampuan intelektual siswa dapat terorganisir secara optimal. Hal ini sejalan dengan yang diungkapkan oleh Shimada \& Becker (1997), yaitu bahwa dalam pembelajaran bahasa Indonesia, rangkaian dari pengetahuan, keterampilan, konsep, prinsip atau aturan diberikan kepada siswa biasanya melalui langkah de-mi langkah. Tentu saja rangkaian ini diajarkan tidak sebagai rangkaian yang terintegrasi dengan kemampuan dan sikap dari setiap siswa sehingga di dalam pikirannya akan terjadi pengorganisasian kemampuan intelektual yang optimal.

Agar seluruh anggota kelas terlibat dalam kegiatan pembelajaran berbicara, hendaklah selalu diingat bahwa hakikatnya berbicara itu berhubungan dengan kegitan berbicara yang lain seperti menyimak, membaca, menulis, dan pokok pembicaraan. Dengan demikian, sebaiknya pengajaran berbicara memperhatikan komunikasi dua arah dan fungsional. Tugas pengajaran adalah pengembangan pengajaran berbicara agar aktivitas kelas dinamis, hidup, dan diminati oleh anak sehingga benar-benar dirasakan sebagai sesuatu kebutuhan untuk mempersiapkan diri terjun ke masyarakat. Untuk mencapai hal itu, dalam pembelajaran berbicara harus diperlihat- 
kan beberapa faktor, misalnya pembicara, pendengar, dan pokok pembicaraan.

Mengontruksi masalah open-ended yang tepat dan baik untuk siswa dengan tingkat kemampuan yang beragam tidaklah mudah. Akan tetapi, berdasarkan penelitian yang dilakukan di Jepang dalam jangka waktu yang cukup panjang, ditemukan beberapa hal yang dapat dijadikan acuan dalam mengkonstruksi masalah, antara lain: (1) sajikan permasalahan melalui situasi fisik yang nyata di mana konsep-konsep bahasa Indonesia dapat diamati dan dikaji siswa; (2) soal-soal pembuktian dapat diubah sedemikian rupa sehingga siswa dapat menemukan hubungan dan sifat-sifat dari variabel dalam persoalan itu; (3) sajikan tema-tema atau topik (karangan) sehingga siswa dapat membuat suatu tulisan berupa paragraf atau karangan; (4) sajikan kalimat yang teracak sehingga siswa dapat menemukan atau menyusun kalimat teracak itu menjadi sistematis; (5) berikan beberapa contoh konkret dalam beberapa kategori sehingga siswa bisa mengelaborasi sifat-sifat dari contoh itu untuk menemukan sifat-sifat dari contoh itu untuk menemukan sifat-sifat yang umum; dan (6) berikan beberapa latihan serupa sehingga siswa dapat menggeneralisasi pekerjaannya.

Pendekatan open-ended ini memiliki beberapa keunggulan. Dalam pembelajaran keunggulan pendekatan open-ended, antara lain: (1) siswa berpartisipasi lebih aktif dalam pembelajaran dan sering mengekspresikan idenya; (2) siswa memiliki kesempatan lebih banyak dalam memanfaatkan pengetahuan dan keterampilan berbahasa secara konprehensif; (3) siswa dengan kemampuan berbahasa rendah dapat merespon permasalahan dengan cara mereka sendiri; (4) siswa secara intrinsik termotivasi untuk memberikan bukti atau penjelasan; dan (5) siswa memiliki pengalaman banyak untuk menemukan sesuatu dalam menjawab permasalahan.

Penelitian sebelumnya mengkaji pendekatan open-ended dalam keterampilan berbicara (Sulyatri, 2013). Sulyatri meneliti tentang pengaruh pendekatan open-ended terhadap keterampilan berbicara siswa kelas VII SMP Negeri 1 Kalaena. Hasil penelitiannya menunjukkan bahwa pendekatan open-ended berpengaruh terhadap keterampilan berbicara siswa kelas VII SMP Negeri 1 Kalaena. Penelitian yang dilakukan oleh Sulyatri memiliki persamaan dengan penelitian ini yaitu meneliti tentang pembel- ajaran berbicara, sedangkan perbedaannya, yaitu pada subjek dan lokasi penelitian.

\section{METODE}

Penelitian ini dilaksanakan di SMP Negeri 1 Ponrang Selatan, Kecamatan Ponrang Selatan, Kabupaten Luwu. Penelitian ini dilakukan pada semester ganjil tahun pelajaran 2015/2016. Jenis penelitian ini adalah penelitian eksperimen. Desain penelitian yang digunakan adalah OneGroup Pre-test-Posttest Design.

Satuan eksperimen dalam penelitian ini adalah siswa kelas VIII SMP Negeri 1 Ponrang Selatan ta-hun pelajaran 2015/2016. Pemilihan kelas eksperimen dalam penelitian ini dilakukan dengan menggunakan teknik random sampling. Kelas yang terpilih sebagai kelas eksperimen yaitu kelas VIII . Perlakuan yang diberikan pada kelas eksperimen yaitu pendekatan open-ended. Untuk pertemuan pertama, kelas ekspe-rimen diberikan pretest untuk mengetahui kemampu-an awal siswa. Kemudian perlakuan (treatment) dibe-rikan pada kelas eksperimen yang diajar dengan menggunakan pendekatan open-ended. Untuk me-ngetahui hasil belajar berbicara siswa maka diberikan posttest.

Instrumen yang digunakan dalam penelitin ini adalah tes hasil belajar yang berupa uraian sebanyak lima nomor. Tes ini terdiri atas pretest dan postest. Pengumpulan data untuk hasil belajar berbicara dilakukan dengan dua tahap. Tahap pertama, yaitu pemberian tes awal. Tes awal diberikan pada saat pertemuan pertama. Tahap kedua, yaitu pemberian tes akhir (posttest) setelah perlakuan dengan pendekatan open-ended. Hasil dari pretest maupun posttest yang sudah diisi oleh siswa diperiksa jawabannya oleh peneliti. Setelah perhitungan selesai, maka hasil dari perhitungan itu adalah nilai yang diperoleh oleh masing-masing siswa. Data yang telah dikumpulkan dengan menggunakan instrumen dianalisis dengan menggunakan analisis statistik deskriptif dan analisis statistik inferensial.

Untuk mengukur hasil belajar siswa berdasarkan pada kategorisasi standar yang ditetapkan oleh Departemen Pendidikan dan Kebudayaan (dalam Nurlela, 2010:28), yaitu skor hasil belajar pada rentang 0-39 (sangat rendah), 40-54 (rendah), 55-74 (sedang), 75-84 (tinggi), dan 85-100 (sangat tinggi). Adapun kriteria peningkatan hasil belajar berbicara siswa, yakni 
$\mathrm{g}<0,3$ (rendah), $0,3 \leq \mathrm{g}<0,7$ (sedang), dan $\mathrm{g} \geq$ 0,7 (tinggi) (Nurhida (2014:49).

\section{Hasil Penelitian}

\section{Hasil Belajar Berbicara Siswa Sebelum dan Sete lah Diajar dengan Menggunakan Pende - katan Open-Ended}

Berikut ini adalah tabel yang berisi tentang gambaran umum hasil belajar berbicara siswa sebelum dan setelah diajar dengan menggunakan pendekatan open-ended yang diperoleh dari data hasil pretest dan posttest.

Tabel 1. Statistik Deskriptif Hasil Belaja Berbicara Siswa

\begin{tabular}{|c|c|c|}
\hline \multirow{2}{*}{ Statistik } & \multicolumn{2}{|c|}{ Nilai Statistik } \\
\hline & Pretest & Postest \\
\hline Ukuran sampel & 39,00 & 9,00 \\
\hline Rata-rata & 60,77 & 81,02 \\
\hline Median & 60,00 & 90,00 \\
\hline Modus & 70,00 & 90,00 \\
\hline Nilai maksimum & 80,00 & 100,00 \\
\hline Nilai minimum & 30,00 & 0,00 \\
\hline Deviasi standar & 13,84 & 12,31 \\
\hline
\end{tabular}

Berdasarkan Tabel 1, data hasil belajar berbicara siswa pada pretest terlihat bahwa nilai rata-rata 60,77 sedangkan pada posttest terlihat bahwa nilai rata-rata 81,02 . Secara deskriptif dapat dikatakan bahwa hasil belajar siswa kelas VIII $_{C}$ menjadi lebih baik dari pada sebelum diberikan pembelajaran dengan menggunakan pendekatan open-ended.

Besarnya peningkatan hasil belajar berbicara siswa yang diajar dengan menggunakan pendekatan open-ended yang dihitung dengan rumus:

$$
\begin{aligned}
& g=\frac{\mathrm{S}_{\text {pos }}-\mathrm{S}_{\text {pre }}}{\mathrm{S}_{\text {mak }}-\mathrm{S}_{\text {pre }}} \\
& g=\frac{81,02-60,77}{100-60,77} \\
& g=\frac{20,25}{39,23} \\
& g=0,52
\end{aligned}
$$

Berdasarkan rumus di atas diperoleh keterangan peningkatan hasil belajar berbicara siswa setelah diterapkannya pembelajaran dengan menggunakan pendekatan open-ended sebesar 0,52 maka peningkatan hasil belajar berbicara siswa yang diajar dengan menggunakan pendekatan open-ended berada pada kategori sedang.

Ketuntasan Belajar Siswa Sebelum dan Sesudah Diajar dengan Pendekatan OpenEnded

Berdasarkan kriteria ketuntasan minimal (KKM) yang berlaku di SMP Negeri 1 Ponrang Selatan yang digunakan untuk menentukan tingkat pencapaian ketuntasan hasil belajar siswa, maka banyaknya siswa yang tuntas dan belum tuntas dapat dilihat pada Tabel berikut.

Tabel 2 menunjukkan bahwa persentase siswa yang tuntas secara klasikal sebesar $100 \%$. Suatu kelas dikatakan tuntas belajarnya (ketuntasan klasikal) jika dalam kelas tersebut terdapat $\geq 85 \%$ siswa yang telah tuntas belajarnya. Berdasarkan uraian di atas, dapat disimpulkan bahwa secara deskriptif hasil belajar berbicara siswa dengan pendekatan open-ended tuntas secara klasikal. Oleh karena itu, penerapan pembelajaran dengan menggunakan pendekatan open-ended dapat dikatakan efektif.

\section{Uji Normalitas}

Pengujian normalitas data dalam penelitian ini dimaksudkan untuk mengetahui apakah data yang diteliti berasal dari populasi berdistribusi normal atau tidak. Adapun keputusan yang diambil dari output SPSS yaitu nilai signifikan dari tabel Test of Normality dikolom Kolmogorov-Smirnov ${ }^{a}$ dengan pedoman pengambilan keputusan adalah: Berdasarkan tabel Tests of Normality diperoleh bahwa nilai probabilitas untuk pretest adalah 0,200 $(p \geq 0,05)$ dan nilai probabilitas untuk posttest adalah 0,052 $(p \geq 0,05)$. Maka dapat disimpulkan bahwa data pada pretest dan posttest berdistribusi normal (simetris).

\section{Hasil Pengujian Hipotesis}

Terjadi peningkatan hasil belajar berbicara siswa dimana skor rata-rata posttest lebih tinggi dari pada skor rata-rata retest (skor rata-rata peningkatan melebihi 0,29). Berdasarkan analisis inferensial 
Tabel 2. Distribusi Ketuntasan Hasil Belajar Siswa

\begin{tabular}{cccccc}
\hline \multirow{2}{*}{ Interval } & \multirow{2}{*}{ Kategori } & \multicolumn{2}{c}{ Pretest } & \multicolumn{2}{c}{ Posttest } \\
\cline { 3 - 6 } & Ketuntasan & Frekuensi & Persentase (\%) & Frekuensi & Persentase \%) \\
\cline { 3 - 6 } & & 10 & 25,64 & 0 & 0 \\
$\geq 60$ & tidak tuntas & 29 & 74,36 & 39 & 100 \\
\hline
\end{tabular}

tampak bahwa untuk uji-t dengan menggunakan taraf signifikan $5 \%$ diperoleh $\mathrm{t}_{\text {tabel }}=1,70$ dan $t_{\text {hitung }}=26,033$. Karena diperoleh nilai $t_{\text {hitung }} \geq t_{\text {tabel }}$ dan pada lampiran tampak bahwa nilai $p$ (one sample test) adalah $0,000<0,05$. Ini berarti bahwa $\mathrm{H}_{0}$ ditolak dan $\mathrm{H}_{1}$ diterima yakni peningkatan hasil belajar berbicara siswa pada kelas yang diajar dengan pendekatan open-ended secara signifikan lebih besar dari 0,29 (kategori sedang). Hal ini juga berarti terjadi peningkatan hasil belajar yang signifikan setelah menggunakan pendekatan open-ended.

Skor rata-rata siswa setelah diajar dengan menggunakan pendekatan open-ended lebih dari 59,9 (KKM). Berdasarkan analisis inferensial menunjukkan bahwa rata-rata posttest siswa setelah diajar dengan menggunakan pendekatan open-ended dengan menggunakan uji-t lebih besar dari 59,9 (KKM). Untuk uji-t dengan menggunakan taraf signifikan 0,05 (5\%) diperoleh $t_{\text {tabel }}=1,70$ dan $t_{\text {hitung }}=6,606$. Karena diperoleh nilai $t_{\text {hitung }} \geq t_{\text {tabel }}$ dan berdasarkan analisis inferensial, yakni tampak bahwa nilai $p$ (one sample test) adalah $0,000<0,05$, maka $\mathrm{H}_{0}$ ditolak dan $\mathrm{H}_{1}$ diterima yakni rata-rata hasil belajar posttest pada kelas yang diajar dengan pendekatan open-ended secara signifikan lebih dari atau sama dengan KKM (60).

\section{Pembahasan}

Hasil analisis data terlihat bahwa hasil belajar berbicara siswa yang diperoleh melalui tes awal sebelum (posttest) dimulainya pembelajaran dan tes akhir sesudah (prettest) pembelajaran dengan menggunakan pendekatan open-ended mengalami peningkatan dari kategori sedang diawal pembelajaran dan berada pada kategori tinggi sesudah pembelajaran.

Hasil analisis statistik deskriptif menunjukkan bahwa hasil belajar berbicara siswa kelas VIII $_{C}$ SMP Negeri 1 Ponrang Selatan secara umum sebelum diterapkan pendekatan openended dikategorikan sedang. Hal ini di tunjukkan dari perolehan nilai rata-rata pretest sebesar 60,77 dari skor ideal 100 dengan standar deviasi
13,84. Hal ini masih menunjukkan bahwa masih ada beberapa siswa yang belum benar-benar menguasai materi sepenuhnya.

Hasil analisis statistik deskriptif yang menunjukkan hasil belajar berbicara siswa kelas VIII $_{C}$ SMP Negeri 1 Ponrang Selatan setelah diterapkan pendekatan open-ended dikategorikan tinggi, dengan perolehan nilai rata-rata posttest sebesar 81,02 dari skor ideal 100 dengan standar deviasi 12,31. Hal ini disebabkan karena meningkatnya minat belajar siswa yang didukung oleh bakat dan kemampuan yang dimilikinya, pendekatan, dan bimbingan belajar yang dilakukan sehingga dapat menguasai materi yang diajarkan atau mencapai ketuntasan belajar. Dengan demikian secara umum dapat disimpulkan bahwa terjadi peningkatan hasil belajar berbicara siswa setelah menerapkan pendekatan openended pada siswa kelas $\mathrm{VIII}_{\mathrm{C}}$ SMP Negeri 1 Ponrang Selatan, dengan kriteria hasil belajar berbicara siswa setelah diterapkan pendekatan open-ended pada siswa kelas VIII $_{C}$ SMP Negeri 1 Ponrang Selatan lebih baik dari sebelum diterapkan pembelajaran pendekatan open-ended.

Sesuai dengan hipotesis penelitian, diperoleh bahwa setelah membandingkan hasil pretest dan postest pada pendekatan open-ended tersebut dengan menggunakan uji- $t$, diperoleh bahwa $\mathrm{H}_{0}$ ditolak dan $\mathrm{H}_{1}$ diterima. Dengan demikian pada pendekatan open-ended mengalami peningkatan. Secara deskriptif telah tercapai ketuntasan klasikal untuk pembelajaran dengan menggunakan pendekatan open-ended yaitu $100 \%$, nilai tersebut telah melampaui kriteria ketuntasan minimal yang telah ditetapkan yaitu $85 \%$. Berdasarkan uraian sebelumnya, penerapan pembelajaran berdasarkan 2 (dua) kriteria yakni (1) rata-rata nilai peningkatan lebih besar dari 0,29 $(0,46>0,29)$, (2) rata-rata nilai posttest melampui nilai KKM $(84,13>59,9)$. Dengan demikian secara umum penerapan pembelajaran dengan menggunakan pendekatan open-ended terjadi peningkatan hasil belajar berbicara pada sampel dan populasi sampel secara keseluruhan.

Berdasarkan pengamatan yang dilakukan oleh penulis masih ditemukannya siswa yang 
kurang memperhatikan penjelasan guru saat menerangkan di depan kelas, masih ada beberapa siswa yang malas membaca buku pelajaran, masih ada siswa yang merasa malu atau raguragu dalam berdiskusi, dan masih didapatkan siswa yang mengganggu temannya saat kegiatan pembelajaran berlangsung.

Pendekatan open-ended mempunyai arti yang cukup penting, karena dalam kegiatan tersebut ketidakjelasan bahan yang disampaikan dapat dibantu dengan menghadirkan pendekatan open-ended (belajar terbuka) sebagai strategi pembejaran. Kerumitan bahan yang akan disampaikan kepada siswa dapat disederhanakan dengan bantuan penerapan pendekatan open-ended.

Peranan pendekatan open-ended tidak terlihat bila penggunaannya tidak sejalan dengan isi dari tujuan pengajaran yang telah dirumuskan. Karena itu, tujuan pengajaran harus dijadikan sebagai pangkal acuan untuk menggunakan salah satu pendekatan pengajaran seperti open-ended. Manakalah diabaikan, maka pendekatan tersebut bukan lagi sebagai pendekatan pengajaran, tetapi sebagai penghambat dalam pencapaian tujuan secara efektif dan efisien.

Siswa yang diajar dengan pendekatan open-ended mengalami peningkatan aktivitas belajar, seperti aktivitas memperhatikan, aktivitas membaca materi pelajaran, aktivitas bekerja sama dalam kelompok diskusi, aktivitas dalam

\section{DAFTAR PUSTAKA}

Nurlela. 2010. Peningkatan Hasil Belajar Biologi Melalui Charta Kelas IV SD Negeri $5 \mathrm{Sa}-$ manggi Kecamatan Simbang Kabupaten Maros. Skripsi. STKIP Yapim Maros.

Permendiknas Nomor 22 Tahun 2006 tentang Standar Isi dan Standar Kompetensi Kurikulum 2006.

Sulyatri. 2013. Pengaruh PendekatanOpen-Ended ter- mengumpulkan tugas, dan aktivitas dalam mempresentasikan hasil diskusi kelompok. Adanya peningkatan aktivitas ini merupakan indikasi bahwa motivasi belajar siswa yang diajar dengan penerapan pendekatan open-ended juga ikut meningkat, sehingga hal ini akan memberikan pengaruh terhadap peningkatan hasil belajar berbicara siswa.

\section{PENUTUP}

Berdasarkan hasil analisis data ditemukan bahwa hasil belajar berbicara siswa kelas VIII SMP Negeri 1 Ponrang Selatan sebelum diterapkan pendekatan open-ended berada pada kategori sedang. Hasil belajar berbicara siswa kelas VIII SMP Negeri 1 Ponrang Selatan setelah diterapkan pendekatan open-ended berada pada kategori tinggi. Terdapat peningkatan hasil belajar berbicara siswa kelas VIII SMP Negeri 1 Ponrang Selatan setelah diterapkan pendekatan open-ended berada pada kategori sedang. Berdasarkan hasil dalam penelitian ini, maka diharapkan kepada peneliti selanjutnya untuk mengkaji masalah yang relevan dengan penelitian ini dengan mengembangkan variabel kearah yang lebih kompleks, seperti mengukur tingkat minat dan motivasi siswa dengan pendekatan openended.

hadap Keterampilan Berbicara Siswa Kelas VII SMP Negeri 1 Kalaena. Skripsi. Universitas Cokroaminoto Palopo.

Shimada, S., \& Becker J.P., (1997). The Open-Ended Approach. A New Proposal for Teaching Mathematics. Virginia : NCTM.

Suherman, dkk. 2001. Strategi Pembelajaran Bahasa Indonesia. Bandung: JICA. 